\title{
Preeclampsia and MicroRNAs
}

\author{
Eric J. Devor, PhD, ${ }^{1}$ Donna A. Santillan, PhD, ${ }^{1}$ Mark K. Santillan, $\mathrm{MD}^{1}$
}

Keywords: pre-eclampsia, MicroRNAs, pregnancy, exosome

\begin{abstract}
Preeclampsia is a critical gestational condition that threatens the life of both mother and child.

One of the most serious aspects of preeclampsia hampering both clinical management and scientific understanding is that there are, as yet, no early warning signs or risk markers. The discovery of microRNAs (miRNAs), tiny post-transcriptional regulators of gene expression, offers potentially fertile ground for developing such markers. The current state of knowledge about miRNAs in preeclampsia is presented along with information regarding miRNA detection in peripheral fluids that could lead to minimally invasive risk assessment.

${ }^{1}$ The Department of Obstetrics and Gynecology, Roy J. and Lucille A. Carver College of Medicine, The University of lowa, lowa City, lowa, USA.
\end{abstract}

\section{Introduction}

Hypertension complicates up to $10 \%$ of all pregnancies worldwide. In the United States, preeclampsia affects $5-7 \%$ of all pregnancies, approximately 300,000 pregnancies a year, yet it disproportionately represents $15 \%$ of all maternal-fetal morbidity and mortality.
Preeclampsia is known to cause immediate maternal-fetal morbidities such as growth restriction, oligohydramnios, fetal death, maternal seizures, stroke, cerebrovascular hemorrhage, and maternal death. ${ }^{1}$ Mothers with a history of preeclampsia are at increased risk of future cardiac disease including myocardial infarction and stroke. $2,3,4$ Children born from preeclamptic pregnancies are also at increased risk of stroke, ${ }^{5}$ epilepsy, ${ }^{6}$ and metabolic, nutritional and blood disease ${ }^{7}$ in later childhood or as an adult. Clearly, preeclampsia has immediate and long term effects on both the fetus and mother. However, its pathogenesis is poorly understood.

The two-stage etiologic model has been the prevailing view of the pathogenesis of preeclampsia. The first stage is the existence of poor placentation exhibited by poor trophoblastic invasion, poor remodeling of spiral arteries, and increased placental necrosis. Despite the many mechanisms that may produce the preeclamptic phenotype,

Please cite this paper as: Devor EJ, Santillan DA, Santillan MK. Preeclampsia and MicroRNAs. Proc Obstet Gynecol. 2013;3(1): Article 2 [ 10 p.]. Available from: http://ir.uiowa.edu/pog/. Free full text article.

Corresponding author: Mark Santillan, MD, Division of Maternal Fetal Medicine, Department of Obstetrics and Gynecology, University of lowa Hospitals and Clinics, 31330 PFP, 200 Hawkins Drive, lowa City, IA 52242, Phone: (319) 356-3180, Email: mark-santillan@uiowa.edu

This is an Open Access article distributed under the terms of the Creative Commons Attribution 3.0 Unported License (http://creativecommons.org/licenses/by/3.0), which permits unrestricted use, distribution, and reproduction in any medium, provided the original work is properly cited. 
data demonstrate that the placenta plays the central role in the development of preeclampsia. In preeclampsia, there is abnormal cytotrophoblast differentiation and apoptosis, ${ }^{8,9}$ incomplete spiral artery invasion, ${ }^{9}$ and decreased blood flow to and from the placenta. Trophoblast necrosis releases cell fragments into the maternal bloodstream which trigger a systemic immunologic response and placental oxidative stress. ${ }^{10,11,12}$ As seen in Figure 1, Redman and Sargent have recently updated this 2 stage model to include an important etiologic component: poor immunoregulation that involves a dysregulation of regulatory T cells, IDO, and dendritic cells. ${ }^{13}$ Multiple processes involving placental dysregulation, endothelial cell dysfunction, immunology, oxidative stress, altered vascular biology, and angiogenesis make finding a singular cause of preeclampsia nearly impossible. ${ }^{14}$ As preeclampsia is a disease resulting from multiple pathways, the development of a predictive model and the search for a therapeutic pathway for preeclampsia may need to come from the regulation of these multiple pathways.

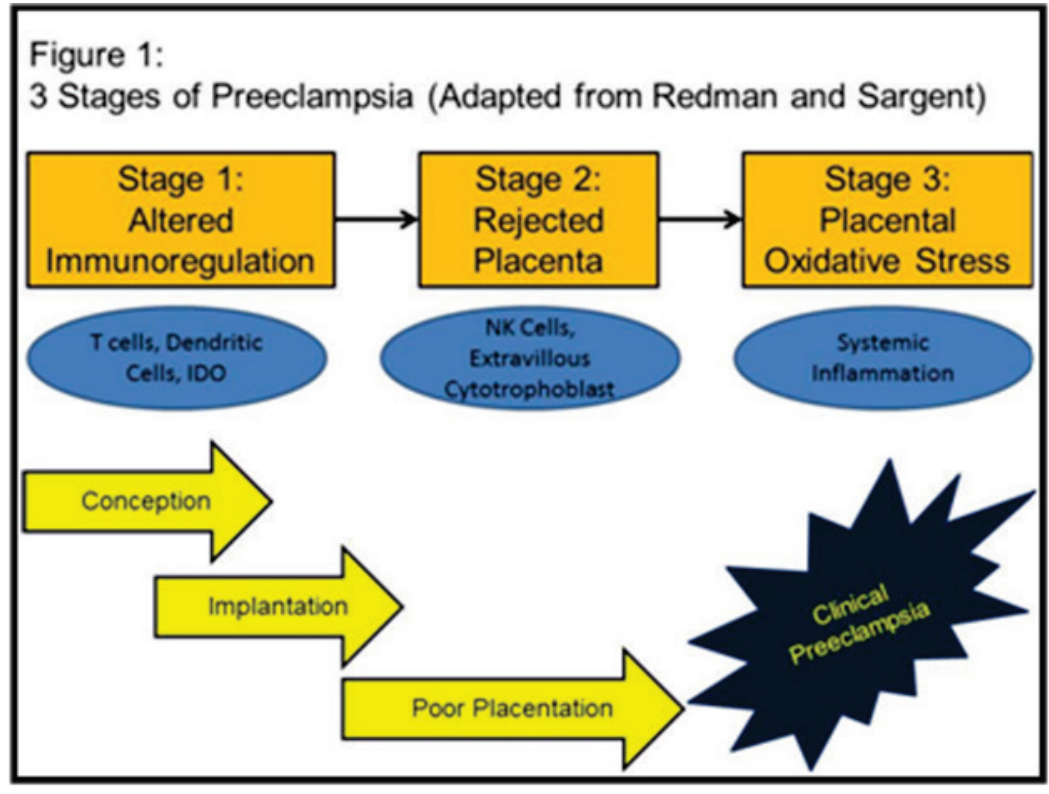

\section{MicroRNAs and Human Disease}

MicroRNAs, as a group, represent a level of regulation that may address all these multiple pathways at once and differentially throughout pregnancy. MicroRNAs (miRNAs) are 21-23nt long regulatory RNAs first identified in Caenorhabtidis elegans in $1993 .^{15,16}$ Since their discovery, miRNAs have been found in nearly every eukaryotic species and have been shown to play critical roles in gene regulation in both normal and pathologic cellular 
processes. ${ }^{17,18}$ The majority of primary miRNA transcripts (pri-miRNAs) are initiated by RNA polymerase II. These transcripts can be from a few hundred to several thousand nucleotides in length and are produced from both inter-genic regions and introns. Pri-miRNAs contain within them one or more shorter sequences that form a characteristic thermodynamically stable hairpin structure. These hairpins in the nucleus induce the formation of an RNA-protein complex composed of the hairpin and RNase III endonuclease DROSHA along with its protein partner DGCR8. ${ }^{19}$ The latter protein binds the pre-miRNA hairpin and DROSHA excises it from the pri-miRNA transcript. Nuclear processing of these miRNAs involves multiple enzymes and proteins including Exportin 5, which binds the hairpin and transports it out of the nucleus. ${ }^{20}$ In the cytoplasm, the pre-miRNA interacts the RNase III endonuclease DICER which binds to the hairpin along with its partner protein TRBP (TAR RNA binding protein). This RNA-protein complex allows DICER to cleave the hairpin in a precise manner to produce a 21-23nt double-stranded RNA composed of the mature miRNA effector sequence and its complement. ${ }^{21,22}$ Finally, this dsRNA is processed by an Argonaute protein, AGO2, which is a primary component of the ribonucleoprotein complex called RISC (RNA induced silencing complex). The mature miRNA strand is selected in RISC and transported to the target messenger RNA (mRNA) where it binds in an antisense orientation to a target sequence in the 3' untranslated region of the message. Once bound, the miRNA:mRNA complex will either participate in mRNA degradation or translational repression of the message. ${ }^{17,23}$ MicroRNA regulation of gene expression is often highly specific in terms of tissue and/or developmental stage or pathology.

Although the mechanisms of these regulatory processes are not fully delineated, their functional importance is evidenced by the fact that miRNAs have been found in nearly every eukaryotic species. As of Release 18 (November, 2011) of the miRNA repository miRBase, there are nearly 2,000 miRNA loci in the human genome. The vast majority of these has been discovered in just the past few years by deep sequencing of specialized tissue targets and are only expressed as a few copies in one tissue type or pathology. The one human disease in which extensive miRNA expression studies have been carried out is cancer. ${ }^{24,25}$ More than twothirds of the current miRNA literature is composed of miRNA studies of cancers. In the field of obstetrics and gynecology, the vast majority of the miRNA literature is addressed to cancers and, in particular, ovarian cancers. However, there have been a number of miRNA expression studies of uterine cancers of which two of the most extensive have been carried out by us. ${ }^{26,27}$ With regard to other OB/GYN pathologic processes, the literature is less extensive. Among these, preeclampsia has received the most attention, but even this literature is small.

\section{MicroRNAs and the Development of Preeclampsia}

To date, there have been four surveys of miRNA expression in preeclampsia (Table 1). Taking these four surveys 
together, a total of 67 different human miRNAs have been shown to be significantly dysregulated in preeclampsia as compared with controls. Among these, only three miRNAs (miR-181a, miR-195, and miR584) are reported in two of the four studies and only one, miR-210, is found in three of the four studies. Replication of increased miR-210 expression in preeclampsia is important as it is known to be the most hypoxia-inducible microRNA. ${ }^{28}$ In addition, there are contradictory data concerning expression of some miRNAs. For example, Hu et al concluded that miR195 is upregulated in placentas from severe preeclamptic pregnancies. ${ }^{29}$ In contrast, Zhu et al demonstrate that miR-195 is downregulated. ${ }^{30}$

Table 1: Summary of the Literature of Differentially Expressed microRNA in

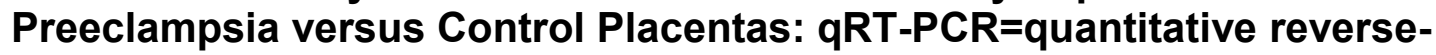
transcriptase polymerase chain reaction

\begin{tabular}{|c|c|c|c|}
\hline Citation & Method & Upregulated & Downregulated \\
\hline $\begin{array}{l}\text { Pineles et al. Am J } \\
\text { Obstetric Gynecol } 2007 \\
\text { (31) }\end{array}$ & qRT-PCR of placenta & $\begin{array}{l}210,155,181 b, \quad 182, \\
200 b, 154,183\end{array}$ & $\mathrm{~N} / \mathrm{A}$ \\
\hline $\begin{array}{l}\text { Hu et al. Clin Chem Lab } \\
\text { Med } 2009 \text { (29) }\end{array}$ & $\begin{array}{l}\text { miR microarray and qRT- } \\
\text { PCR of severe PE placenta }\end{array}$ & $\begin{array}{l}16,29 b, 195,26 b, 181 a, \\
335,222\end{array}$ & N/A \\
\hline $\begin{array}{l}\text { Zhu et al. Am J Obstet } \\
\text { Gynecol } 2009(30)\end{array}$ & $\begin{array}{l}\text { miR microarray and qRT- } \\
\text { PCR of severe PE placenta }\end{array}$ & $\begin{array}{l}181 \mathrm{a}, 584,30 \mathrm{a}-3 \mathrm{p}, 210 \\
152,517,518 \mathrm{~b}, 519 \mathrm{e}, \\
638,296,362\end{array}$ & $\begin{array}{l}101,10 \mathrm{~b}, 218,590,204, \\
32,126,18 \mathrm{a}, 19 \mathrm{a}, 411,377, \\
154,625,144,195,150,1, \\
18 \mathrm{~b}, 363,342-3 \mathrm{p}, 450, \\
223,374\end{array}$ \\
\hline $\begin{array}{l}\text { Enquobahrie et al. Am J } \\
\text { Obstet Gynecol } 2010 \text { (32) }\end{array}$ & $\begin{array}{l}\text { miR microarray and qRT- } \\
\text { PCR of placenta }\end{array}$ & 210 & $\begin{array}{l}328,584, \quad 139-5 \mathrm{p}, \quad 500, \\
1247,340-5 \mathrm{p}, 1\end{array}$ \\
\hline $\begin{array}{l}\text { Mayor-Lynn et al. Repro } \\
\text { Sci } 2010 \text { (33) }\end{array}$ & $\begin{array}{l}\text { miR microarray and qRT- } \\
\text { PCR of placenta }\end{array}$ & 493 & $15 b, 181 a, 210,483-5 p$ \\
\hline $\begin{array}{l}\text { Zhang et al. Am J Obstet } \\
\text { Gynecol } 2010 \text { (34) }\end{array}$ & $\begin{array}{l}\text { qRT-PCR mechanism paper: } \\
\text { miR-155 downregulates } \\
\text { CYR61 gene involved in } \\
\text { trophoblast function and } \\
\text { angiogenic cells. }\end{array}$ & N/A & $\mathrm{N} / \mathrm{A}$ \\
\hline
\end{tabular}

It is important to note that, though there is ample evidence that miRNAs are dysregulated in preeclampsia, these studies were all carried out using RNA from placental tissues obtained after the patients had delivered. Methodologically, this clearly limits the use of miRNAs as a predictive tool. As obtaining placental tissue biopsies during gestation is neither feasible nor ethical, predictive miRNA assays must be done on RNA from a different source. Recently, Wu et al. showed that miRNA dysregulation can be detected in plasma drawn from women at 37 to 40 weeks gestation. ${ }^{35}$ Their study confirmed the 
results of previous studies of placental tissues by detecting significant dysregulation of four miRNAs, miR130a, miR-144, miR-181a, and miR574-5p compared with plasma RNA from controls. They discovered a further eleven significantly dysregulated miRNAs not previously reported in other preeclampsia studies. This demonstrates that potentially meaningful miRNA expression changes can be detected in plasma samples. Having the ability to assay miRNA expression in a peripheral fluid opens the opportunity to carry out longitudinal cohort studies of preeclampsia using a minimally invasive sampling technique.

First stimulated by an observation that very small microvesicular bodies shed by cultured human tumor cells into the media displayed molecular markers characteristic of the tumor plasma membranes themselves, Douglas Taylor and colleagues have shown that miRNAs, along with a specific range of mRNAs, that are shed by cancer cells into the blood stream are encapsulated within the structures called exosomes. ${ }^{36-}$ ${ }^{42}$ Importantly, these studies showed that the principle sources of RNA-containing exosomes are placenta and solid tumors. Indeed, the most prolific exosome-producing tissue is the placenta. ${ }^{43,44}$ Several studies have shown that miRNAs in placental-derived exosomes can be reliably assayed in plasma and that they appear to participate in numerous crucial functions, including those related to immune suppression and angiogenesis. ${ }^{45}$ With respect to the reliability of these plasma-based miRNA assays, we recently determined expression of 377 human miRNAs in both placental tissue and plasma, albeit in a single individual. However, of the 315 miRNAs expressed in placenta, we found that $286 \quad(91 \%)$ were also detectable in plasma. Moreover, there was a highly significant correlation in expression levels of miRNAs $(r=0.6, p$ $<.001, \mathrm{df}=284$ ).

\section{Conclusion}

Preeclampsia is a serious and lifethreatening gestational condition whose etiology is still not well understood. In addition to its pathology, both the diagnosis and clinical management of preeclampsia are subjects of debate and controversy. One of the most important aspects impeding advances in understanding preeclampsia is that the majority of studies of the condition are carried out only after clinical signs such as progressive proteinuria and hypertension are clearly manifest. Thus, identification of a minimally invasive marker or markers that correlate with risk will be a major advance informing both clinical management and studies of pathogenesis. The discovery of miRNAs, gene expression regulators reliably detectable in both tissue and peripheral fluids, offers a potentially fertile field for identifying such markers.

\section{References}

1. Villar K, Say L, Gülmezoglu AM, Merialdi M, Lindheimer MD, Betran AP, Piaggio G. Eclampsia and preeclampsia: a health problem for 2000 years. In: Critchley $\mathrm{H}$, MacLean $A B$, Poston L, Walker JJ, eds. Preeclampsia. London: RCOG Press; 2003. P. 189-207. 
2. Garovic VD, Hayman SR. Hypertension in pregnancy: an emerging risk factor for cardiovascular disease. Nat Clin Pract Nephrol. 2007 Nov;3(11):613-22. PubMed PMID: 17957198.

http://dx.doi.org/10.1038/ncpneph0623

3. Lykke JA, Langhoff-Roos J, Sibai BM, Funai EF, Triche EW, Paidas MJ. Hypertensive pregnancy disorders and subsequent cardiovascular morbidity and type 2 diabetes mellitus in the mother. Hypertension. 2009 Jun;53(6):944-51. doi: 10.1161/HYPERTENSIONAHA.109.130 765. Epub 2009 May 11. PubMed PMID: 19433776.

4. Magnussen EB, Vatten LJ, Smith GD, Romundstad PR. Hypertensive disorders in pregnancy and subsequently measured cardiovascular risk factors. Obstet Gynecol. 2009 Nov;114(5):961-70. doi: 10.1097/AOG.0b013e3181bb0dfc.

PubMed PMID: 20168095.

5. Kajantie E, Eriksson JG, Osmond C, Thornburg K, Barker DJ. Pre-eclampsia is associated with increased risk of stroke in the adult offspring: the Helsinki birth cohort study. Stroke. 2009 Apr;40(4):1176-80. doi: 10.1161/STROKEAHA.108.538025.

Epub 2009 Mar 5. PubMed PMID: 19265049.

6. Wu CS, Sun $Y$, Vestergaard $M$, Christensen J, Ness RB, Haggerty CL, Olsen J. Preeclampsia and risk for epilepsy in offspring. Pediatrics. 2008 Nov;122(5):1072-8. doi: 10.1542/peds.2007-3666. PubMed PMID: 18977989.
7. Wu CS, Nohr EA, Bech BH, Vestergaard M, Catov JM, Olsen J. Health of children born to mothers who had preeclampsia: a population-based cohort study. Am J Obstet Gynecol. 2009 Sep;201(3):269.e1-269.e10. doi: 10.1016/j.ajog.2009.06.060. PubMed PMID: 19733276.

8. DiFederico E, Genbacev O, Fisher SJ. Preeclampsia is associated withwidespread apoptosis of placental cytotrophoblasts within the uterine wall. Am J Pathol. 1999 Jul;155(1):293-301. PubMed PMID: 10393861; PubMed Central PMCID: PMC1866652. http://dx.doi.org/10.1016/S00029440(10)65123-1

9. Kadyrov M, Kingdom JC, Huppertz B. Divergent trophoblast invasion and apoptosis in placental bed spiral arteries from pregnancies complicated by maternal anemia and early-onset preeclampsia/intrauterine growth restriction. Am J Obstet Gynecol. 2006 Feb;194(2):557-63. PubMed PMID: 16458661.

http://dx.doi.org/10.1016/j.ajog.2005.07. 035

10. Formigli L, Papucci L, Tani A, Schiavone N, Tempestini A, Orlandini GE, Capaccioli S, Orlandini SZ. Aponecrosis: morphological and biochemical exploration of a syncretic process of cell death sharing apoptosis and necrosis. J Cell Physiol. 2000 Jan;182(1):41-9. PubMed PMID: 10567915.

http://dx.doi.org/10.1002/(SICI)10974652(200001)182:1<41::AIDJCP5>3.0.CO;2-7 
11. Goswami D, Tannetta DS, Magee LA, Fuchisawa A, Redman CW, Sargent IL, von Dadelszen P. Excess syncytiotrophoblast microparticle shedding is a feature of early-onset preeclampsia, but not normotensive intrauterine growth restriction. Placenta. 2006 Jan;27(1):56-61. Epub 2005 Jan 25. PubMed PMID: 16310038. http://dx.doi.org/10.1016/j.placenta.2004 .11 .007

12. Knight M, Duley L, Henderson-Smart DJ, King JF. Antiplatelet agents for preventing and treating pre-eclampsia. Cochrane Database Syst Rev. 2000;(2):CD000492. Review. Update in: Cochrane Database Syst Rev. 2007;(2):CD000492. PubMed PMID: 10796208.

13. Redman CW, Sargent IL. Immunology of pre-eclampsia. Am J Reprod Immunol. 2010 Jun;63(6):534-43. doi: 10.1111/j.1600-0897.2010.00831.x.

Epub 2010 Mar 23. PubMed PMID: 20331588.

14. Santillan MK, Santillan DA, Sigmund CD, Hunter SK. From molecules to medicine: a future cure for preeclampsia? Drug News Perspect. 2009 Nov;22(9):531-41. doi: 10.1358/dnp.2009.22.9.1435464.

PubMed PMID: 20072730.

15. Lee RC, Feinbaum RL, Ambros V. The C. elegans heterochronic gene lin-4 encodes small RNAs with antisense complementarity to lin-14. Cell. 1993 Dec 3;75(5):843-54. PubMed PMID: 8252621.

http://dx.doi.org/10.1016/0092-

8674(93)90529-Y

16. Wightman B, Ha I, Ruvkun G. Posttranscriptional regulation of the heterochronic gene lin-14 by lin-4 mediates temporal pattern formation in C. elegans. Cell. 1993 Dec 3;75(5):85562. PubMed PMID: 8252622. http://dx.doi.org/10.1016/00928674(93)90530-4
17. Bartel DP. MicroRNAs: target recognition and regulatory functions. Cell. 2009 Jan 23;136(2):215-33. doi: 10.1016/j.cell.2009.01.002. PubMed PMID: 19167326.

18. Kim VN, Han J, Siomi MC. Biogenesis of small RNAs in animals. Nat Rev Mol Cell Biol. 2009 Feb;10(2):126-39. doi: 10.1038/nrm2632. PubMed PMID: 19165215.

19. Han J, Lee Y, Yeom KH, Kim YK, Jin $\mathrm{H}$, Kim VN. The Drosha-DGCR8 complex in primary microRNA processing. Genes Dev. 2004 Dec 15;18(24):3016-27. Epub 2004 Dec 1. PubMed PMID: 15574589; PubMed Central PMCID: PMC535913. http://dx.doi.org/10.1101/gad.1262504

20. Yi R, Qin Y, Macara IG, Cullen BR. Exportin-5 mediates the nuclear export of pre-microRNAs and short hairpin RNAs. Genes Dev. 2003 Dec 15;17(24):3011-6. Epub 2003 Dec 17. PubMed PMID: 14681208; PubMed Central PMCID: PMC305252. http://dx.doi.org/10.1101/gad.1158803

21. Chendrimada TP, Gregory RI, Kumaraswamy E, Norman J, Cooch N, Nishikura K, Shiekhattar R. TRBP recruits the Dicer complex to Ago2 for microRNA processing and gene silencing. Nature. 2005 Aug 4;436(7051):740-4. Epub 2005 Jun 22. PubMed PMID: 15973356; PubMed Central PMCID: PMC2944926. http://dx.doi.org/10.1038/nature03868

22. Haase $A D$, Jaskiewicz $L$, Zhang $H$, Lainé S, Sack R, Gatignol A, Filipowicz W. TRBP, a regulator of cellular PKR and HIV-1 virus expression, interacts with Dicer and functions in RNA silencing. EMBO Rep. 2005 Oct;6(10):961-7. PubMed PMID: 16142218; PubMed Central PMCID: PMC1369185.

http://dx.doi.org/10.1038/sj.embor.74005 09 
23. Lewis BP, Burge CB, Bartel DP. Conserved seed pairing, often flanked by adenosines, indicates that thousands of human genes are microRNA targets. Cell. 2005 Jan 14;120(1):15-20. PubMed PMID: 15652477. http://dx.doi.org/10.1016/j.cell.2004.12.0 35

24. Calin GA, Sevignani C, Dumitru CD, Hyslop T, Noch E, Yendamuri S, Shimizu M, Rattan S, Bullrich F, Negrini $M$, Croce CM. Human microRNA genes are frequently located at fragile sites and genomic regions involved in cancers. Proc Natl Acad Sci U S A. 2004 Mar 2;101(9):2999-3004. Epub 2004 Feb 18. PubMed PMID: 14973191; PubMed Central PMCID: PMC365734.

25. Spizzo R, Nicoloso MS, Croce CM, Calin GA. SnapShot: MicroRNAs in Cancer. Cell. 2009 May 1;137(3):586586.e1. doi: 10.1016/j.cell.2009.04.040. PubMed PMID: 19410551.

26. Devor EJ, Hovey AM, Goodheart MJ, Ramachandran S, Leslie KK. microRNA expression profiling of endometrial endometrioid adenocarcinomas and serous adenocarcinomas reveals profiles containing shared, unique and differentiating groups of microRNAs. Oncol Rep. 2011 Oct;26(4):995-1002. doi: 10.3892/or.2011.1372. Epub 2011 Jul 1. PubMed PMID: 21725615; PubMed Central PMCID: PMC3518452.

27. Devor EJ, DE Mik JN, Ramachandran S, Goodheart MJ, Leslie KK. Global dysregulation of the chromosome 14q32 imprinted region in uterine carcinosarcoma. Exp Ther Med. 2012 Apr;3(4):677-682. Epub 2012 Jan 25. PubMed PMID: 22969950; PubMed Central PMCID: PMC3438812. doi: 10.3892/etm.2012.458
28. Chan YC, Banerjee J, Choi SY, Sen CK. miR-210: the master hypoxamir. Microcirculation. 2012 Apr;19(3):215-23. doi: 10.1111/j.1549-8719.2011.00154.x. PubMed PMID: 22171547; PubMed Central PMCID: PMC3399423.

29. Hu Y, Li P, Hao S, Liu L, Zhao J, Hou $Y$. Differential expression of microRNAs in the placentae of Chinese patients with severe pre-eclampsia. Clin Chem Lab Med. 2009;47(8):923-9. doi: 10.1515/CCLM.2009.228. PubMed PMID: 19642860.

30. Zhu XM, Han T, Sargent IL, Yin GW, Yao YQ. Differential expression profile of microRNAs in human placentas from preeclamptic pregnancies vs normal pregnancies. Am J Obstet Gynecol. 2009 Jun;200(6):661.e1-7. doi: 10.1016/j.ajog.2008.12.045.Epub 2009 Mar 14. PubMed PMID: 19285651.

31. Pineles $B L$, Romero R, Montenegro D, Tarca AL, Han YM, Kim YM, Draghici S, Espinoza J, Kusanovic JP, Mittal P, Hassan SS, Kim CJ. Distinct subsets of microRNAs are expressed differentially in the human placentas of patients with preeclampsia. Am J Obstet Gynecol. 2007 Mar;196(3):261.e1-6. PubMed PMID: 17346547. http://dx.doi.org/10.1016/j.ajog.2007.01. 008

32. Enquobahrie DA, Abetew DF, Sorensen TK, Willoughby D, Chidambaram K, Williams MA. Placental microRNA expression in pregnancies complicated by preeclampsia. Am J Obstet Gynecol. 2011 Feb;204(2):178.e12-21. doi: 10.1016/j.ajog.2010.09.004. Epub 2010 Nov 20. PubMed PMID: 21093846; PubMed Central PMCID: PMC3040986. 
33. Mayor-Lynn K, Toloubeydokhti T, Cruz AC, Chegini N. Expression profile of microRNAs and mRNAs in human placentas from pregnancies complicated by preeclampsia and preterm labor. Reprod Sci. 2011 Jan;18(1):46-56. doi: 10.1177/1933719110374115. Epub 2010 Nov 15. PubMed PMID: 21079238; PubMed Central PMCID: PMC3343068.

34. Zhang $Y$, Diao Z, Su L, Sun $H$, Li R, Cui H, Hu Y. MicroRNA-155 contributes to preeclampsia by down-regulating CYR61. Am J Obstet Gynecol. 2010 May;202(5):466.e1-7. doi: 10.1016/j.ajog.2010.01.057. PubMed PMID: 20452491.

35. Wu L, Zhou H, Lin H, Qi J, Zhu C, Gao Z, Wang $\mathrm{H}$. Circulating microRNAs are elevated in plasma from severe preeclamptic pregnancies. Reproduction. 2012 Mar;143(3):389-97. doi: 10.1530/REP-11-0304. Epub 2011 Dec 20. PubMed PMID: 22187671.

36. Sabapatha A, Gercel-Taylor C, Taylor DD. Specific isolation of placentaderived exosomes from the circulation of pregnant women and their immunoregulatory consequences. Am J Reprod Immunol. 2006 Nov-Dec;56(56):345-55. PubMed PMID: 17076679. http://dx.doi.org/10.1111/j.16000897.2006.00435.x

37. Taylor DD, Doellgast GJ. Quantitation of peroxidase-antibody binding to membrane fragments using column chromatography. Anal Biochem. 1979 Sep 15;98(1):53-9. PubMed PMID: 396817. http://dx.doi.org/10.1016/00032697(79)90704-8

38. Taylor DD, Gercel-Taylor C. MicroRNA signatures of tumor-derived exosomes as diagnostic biomarkers of ovarian cancer. Gynecol Oncol. 2008 Jul;110(1):13-21. doi: 10.1016/j.ygyno.2008.04.033. Erratum in: Gynecol Oncol. 2010 Jan;116(1):153. PubMed PMID: 18589210.
39. Adair CD, Buckalew V, Taylor K, Ernest JM, Frye AH, Evans C, Veille JC. Elevated endoxin-like factor complicating a multifetal second trimester pregnancy: treatment with digoxin-binding immunoglobulin. Am J Nephrol. 1996;16(6):529-31. PubMed PMID: 8955766. http://dx.doi.org/10.1159/000169054

40. Taylor DD, Homesley HD, Doellgast GJ. Binding of specific peroxidaselabeled antibody to placental-type phosphatase on tumor-derived membrane fragments. Cancer Res. 1980 Nov;40(11):4064-9. PubMed PMID: 7008934.

41. Taylor DD, Homesley HD, Doellgast GJ. "Membrane-associated" immunoglobulins in cyst and ascites fluids of ovarian cancer patients. Am J Reprod Immunol. 1983 Jan-Feb;3(1):711. PubMed PMID: 6859379.

42. Taylor EL, Gant TW. Emerging fundamental roles for non-coding RNA species in toxicology. Toxicology. 2008 Apr 3;246(1):34-9. doi: 10.1016/j.tox.2007.12.030. Epub 2008 Jan 15. Review. PubMed PMID: 18289762.

43. Taylor DD, Bohler HC, Gercel-Taylor C. Pregnancy-linked suppression of TcR signaling pathways by a circulating factor absent in recurrent spontaneous pregnancy loss (RPL). Mol Immunol. 2006 Apr;43(11):1872-80. Epub 2005 Dec 20. PubMed PMID: 16368145. http://dx.doi.org/10.1016/j.molimm.2005. 10.008

44. Mincheva-Nilsson L, Baranov V. The role of placental exosomes in reproduction. Am J Reprod Immunol. 2010 Jun;63(6):520-33. doi: 10.1111/j.1600-0897.2010.00822.x. Epub 2010 Mar 11. PubMed PMID: 20331583. 
45. Gilad S, Meiri E, Yogev Y, Benjamin S, Lebanony D, Yerushalmi N, Benjamin $\mathrm{H}$, Kushnir M, Cholakh $\mathrm{H}$, Melamed $\mathrm{N}$, Bentwich Z, Hod M, Goren Y, Chajut A. Serum microRNAs are promising novel biomarkers. PLoS One. 2008 Sep 5;3(9):e3148. doi: 10.1371/journal.pone.0003148. PubMed PMID: 18773077; PubMed Central PMCID: PMC2519789. 